\title{
Kinetics of silicic acid uptake by natural diatom assemblages in two Gulf Stream warm-core rings
}

\author{
David M. Nelson, Mark A. Brzezinski* \\ College of Oceanography, Oregon State University, Corvallis, Oregon 97331, USA
}

\begin{abstract}
We performed ${ }^{30}$ Si tracer experiments to measure the uptake rates of silicic acid by natural diatom assemblages in 2 Gulf Stream warm-core rings as a function of the extracellular silicic acid concentration. The experiments were performed at and near the centers of rings 81-D and 82-B, and included 5 sampling dates in late spring, summer and autumn, when silicic acid was undetectable to conventional analyses $(<0.2 \mu \mathrm{M})$ throughout the upper 20 to $30 \mathrm{~m}$. Uptake was measurably substratelimited only at those stations where silicic acid was undetectable. Concentrations of 2.5 to $3 \mu \mathrm{M} \mathrm{Si}(\mathrm{OH})_{41}$ which typified ring $82-\mathrm{B}$ before the development of the seasonal thermocline, were high enough to support maximum uptake rates. When substrate limitation was present the dependence of the uptake rate on silicic acid concentration exhibited hyperbolic saturation kinetics, with half-saturation constants $\left(\mathrm{K}_{\mathrm{s}}\right)$ ranging from 0.53 to $0.90 \mu \mathrm{M}$. This range is considerably lower than that reported previously for natural diatom assemblages $(1.5$ to $3.7 \mu \mathrm{M})$. A numerical simulation indicates that a diatom species with a $\mathrm{K}_{\mathrm{s}}$ value typical of the ring assemblages would outcompete most diatom species whose silicon kinetics have been examined in culture, not only under conditions of continuously low silicic acid concentration but with the sporadic, pulsed nutrient injections that appear to characterize warm-core ocean eddies. Previous studies of silicic acid uptake kinetics in natural waters have all been conducted in relatively nutrient-rich systems and the lower $\mathrm{K}_{\mathrm{s}}$ values we report here for 2 Gulf Stream warm-core rings indicate that diatoms growing in severely nutrient-depleted surface waters have a higher affinity for silicic acid than those growing in more eutrophic habitats. If this is true for other nutrient-depleted environments such as the tropics and mid-ocean gyres, the likelihood of significant silicon limitation in such systems is diminished.
\end{abstract}

\section{INTRODUCTION}

The potential role of silicon as a limiting nutrient for the siliceous phytoplankton has been recognized for many years (e.g. Thompson \& Robinson 1932, Cooper 1933, Dugdale \& Goering 1970, Nelson \& Goering 1978). Diatoms have an absolute silicon requirement for growth (Lewin 1962) and most diatoms incorporate silicon and nitrogen in a mole ratio of about $1: 1$ (Brzezinski 1985). The magnitude of this silicon demand by diatoms is such that the first-order vertical profile of dissolved silicic acid in the ocean is similar to those of nitrate and phosphate; there is depletion of all 3 nutrients within the euphotic zone, and the depth interval between ca 100 and $500 \mathrm{~m}$ is characterized by pronounced vertical concentration gradients (e.g. Red-

- Present address: Department of Biological Sciences, University of California, Santa Barbara, California 93106, USA field et al. 1963, Bainbridge 1980). Over large areas of the ocean the concentration of silicic acid in the surface layer is <1 $\mu \mathrm{M}$ (e.g. Baimbridge 1980) and reports of undetectable concentrations (generally $<0.2 \mu \mathrm{M}$ ) are not uncommon (e.g. Pratt 1965, Walsh et al. 1971 , Anderson \& Dyrssen 1981, Fox et al. 1983, 1984b).

The kinetics of both silicic acid uptake and siliconlimited growth of several diatom species have been examined in culture (e.g. Guillard et al. 1973, Paasche 1973a,b, Nelson et al. 1976, Conway \& Harrison 1977. Jacques 1983). These kinetic studies (summarized by Nelson in press) have shown that limitation of both the uptake rate and the cell division rate by extracellular silicic acid concentrations conforms approximately to a Michaelis-Menten saturation curve, as first proposed by Dugdale (1967) for nitrogen and demonstrated by Goering et al. (1973) for silicon. Reported half-saturation constants $\left(\mathrm{K}_{\mathrm{s}}\right)$ for silicic acid uptake by diatoms in culture range from 0.3 to $22 \mu \mathrm{M}$ (Conway \& Harrison 1977. Jacques 1983), but only Antarctic species have 
exhibited $K_{s}$ values $>5 \mu M$ (Jacques 1983). Half-saturation constants for silicon-limited growth are considerably lower, ranging from $<0.1$ to $1.4 \mu \mathrm{M}$ (Paasche 1973a, 1975). Comparison of these kinetic results with silicic acid concentrations observed in oceanic surface waters (e.g. Bainbridge 1980) implies that nearly all diatom species that have been examined in culture would experience rather severe limitation of their uptake rates and readily detectable limitation of their division rates at the silicic acid concentrations typical of the large mid-ocean gyres and the tropics.

The inferred limitation of uptake rates has been measured directly in tracer studies performed at sea on natural diatom assemblages (e.g. Goering et al. 1973, Azam \& Chisholm 1976, Nelson et al. 1981). These studies provide no information on the uptake kinetics of individual species, but do show what range of silicic acid concentrations can limit the rate of uptake by diatoms under natural conditions. These experiments have tended to confirm the results of culture studies in the sense that uptake by natural diatom assemblages at sea also conforms to the hyperbolic model. Apparent half-saturation constants reported in field studies to date range from 1.5 to $3.7 \mu \mathrm{M}$ (Azam \& Chisholm 1976, Nelson et al. 1981), which is in the same general range observed for uptake by temperate species in culture studies.

Previous field and laboratory studies of silicon limitation have emphasized relatively nutrient-rich coastal and subpolar systems, and diatoms isolated from them. Very few kinetic data exist for oceanic diatoms in culture studies (Guillard et al. 1973, Nelson et al. 1976) and the degree of silicon limitation experienced by natural diatom assemblages in severely nutrientdepleted surface waters has not previously been addressed. We report here the results of experiments to determine the kinetics of silicic acid uptake by natural diatom assemblages in 2 Gulf Stream warm-core rings. These studies included 5 experiments in waters from which silicic acid (as well as nitrate, phosphate and ammonium) had been depleted to concentrations undetectable by conventional methods. Diatoms are usually a smaller component of the phytoplankton in such systems than they are in more nutrient-rich waters, and difficulty in satisfying their silicon requirement has been offered as one possible explanation of the diminished abundance of diatoms in oligotrophic waters (e.g. Guillard \& Kilham 1977). The results reported here show that diatom assemblages from Gulf Stream rings have a considerably higher affinity for silicic acid (i.e. lower $K_{s}$ ) than do natural diatom assemblages in more eutrophic habitats. This indicates that at least some diatom species are better adapted to silicon-depleted environments than previous data have shown

\section{METHODS}

These experiments were conducted in Gulf Stream warm-core ring 81-D aboard the RV 'Atlantis II' on September 23 and October 2, 1981 and in ring 82-B aboard the RV 'Knorr' on April 23, May 4 and June 15 , 20 and 26, 1982. Each experiment was conducted at the center of the ring, as estimated from XBT surveys, drifter tracks and preliminary analyses of satellite data on sea-surface temperature (all of which were available to us at sea). Subsequent detailed analysis of satellite imagery (Hooker \& Olson 1985) indicates that all experiments were performed within $26 \mathrm{~km}$ of the ring center, and all were within the hydrographic core of the ring. On both sampling dates in ring 81-D (Sep 23 and Oct 2) and all June sampling dates in ring 82-B silicic acid was undetectable to conventional colorimetric analysis $(<0.2 \mu \mathrm{M}$ ) in the upper 20 to $30 \mathrm{~m}$ (Fox et al. 1983,1984 b). In ring 82-B in April and early May silicic acid was readily measurable $(2.5$ to $2.9 \mu \mathrm{M})$ throughout the upper $300 \mathrm{~m}$ (Fox et al. 1984a).

For each experiment we collected a 60 I seawater sample from the depth to which $60 \%$ of the surface irradiance penetrated ( 3 to $5 \mathrm{~m}$ ), as described by Nelson et al. (1985). Irradiance at this depth ranged from 365 to $2000 \mu \mathrm{E} \mathrm{m}^{-2} \mathrm{~s}^{-1}$ (Phinney et al. 1983, 1984) and this depth was chosen on the expectation that light should be neither strongly limiting nor strongly inhibiting to photosynthesis. ${ }^{14} \mathrm{C}$ measurements of photosynthetic rates in ring $82-B$ (Hitchcock et al. 1985) indicate that the $60 \%$ light depth was generally at or near the maximum in the rate of photosynthesis per unit chlorophyll. Subsamples for kinetic studies of silicic acid uptake were drawn into seven 2.81 polycarbonate incubation bottles. Six were injected with ${ }^{30} \mathrm{Si}$ labelled silicic acid tracer solution (95.20 atom \% ${ }^{30} \mathrm{Si}$ ) and the seventh analyzed for particulate silica as described by Brzezinski \& Nelson (1989). Final tracer concentrations ranged from 0.25 to $5.0 \mu \mathrm{M}$ above ambient. The samples were then incubated in daylight for 4 to $6 \mathrm{~h}$ on deck in a plexiglas water bath that was maintained at sea-surface temperature by a continuous flow of surface seawater and covered with neutraldensity screening to simulate in situ light intensity. The incubations were terminated by filtering each sample through a $0.6 \mu \mathrm{m}$ pore-size polycarbonate membrane filter (Nuclepore, Inc.). Each filter was then folded in quarters, placed in a plastic petri dish and dried at $60^{\circ} \mathrm{C}$.

The ${ }^{30} \mathrm{Si}$ content of the particulate silica collected on each filter was determined by mass spectrometry. The particulate silica was dissolved in $0.2 \mathrm{ml}$ of $2.9 \mathrm{M}$ hydrofluoric acid, and then 2.0 umoles of ${ }^{29} \mathrm{Si}$ carrier $\left(0.2 \mathrm{ml}\right.$ of $10.0 \mathrm{mM} \mathrm{Na}_{2} \mathrm{SiO}_{3}$ solution; 95.28 atom $\%{ }^{29} \mathrm{Si}$ ) was added to assure a strong signal. The Si was preci- 
pated from this solution as $\mathrm{BaSiF}_{6}$, which was purified, dried and analyzed by solid-phase mass spectrometry as described by Nelson \& Goering (1977). The mass spectrometry was performed on a Nuclide Corp. Model 3-60 (3 in. $\left[7.6 \mathrm{~cm}\right.$ ] radius, $60^{\circ}$ deflection) magnetic sector mass spectrometer fitted with a direct insertion probe for solid samples. Data from 7 successive scans were recorded and analyzed for each sample. Analysis of isotopic standards and repetitive analysis of single samples indicate that under these conditions the mass spectrometry is subject to errors of less than \pm 0.05 atom $\%$, which translates into errors of \pm 1 to $5 \%$ in the uptake rate, depending on the particulate silica content of the sample and the amount of ${ }^{30} \mathrm{Si}$ enrichment.

The specific uptake rate of silicic acid (V) in units of moles Si taken up per mole particulate Si initially present per unit time, which reduces dimensionally to (time $\left.{ }^{-1}\right)$, was calculated from the ${ }^{30} \mathrm{Si}$ content of each sample and the incubation conditions as described by Goering et al. (1973). Analytically undetectable ambient concentrations of silicic acid $(<0.2 \mu \mathrm{M})$ were assigned a value of $0.1 \pm 0.1 \mu \mathrm{M}$ for these calculations. The resulting uncertainties in both $\left[\mathrm{Si}(\mathrm{OH})_{4}\right]$ and $\mathrm{V}$ range from $\pm 2 \%$ at the $5.0 \mu \mathrm{M}$ additions to $\pm 29 \%$ at the $0.25 \mu \mathrm{M}$ additions (see 'Discussion'). Because silicic acid taken up by diatoms can be deposited as siliceous hard parts within minutes (e.g. Darley et al. 1976), V represents the overall rate of silicification, rather than transport across the cell membrane or any other single step in the process. This is the same operational definition of the term 'uptake' used in all previous laboratory and field studies of silicon uptake kinetics (e.g. Paasche 1973b, Azam \& Chisholm 1976, Jacques 1983) but differs from that used in physiological studies of membrane transport (e.g. Sullivan 1977, Werner 1977). The dependence of $\mathrm{V}$ upon the extracellular silicic acid concentration, $\left[\mathrm{Si}(\mathrm{OH})_{4}\right]$, was described by fitting the Michaelis-Menten equation

$$
V=V_{\max } \frac{\left[\mathrm{Si}(\mathrm{OH})_{4}\right]}{\mathrm{K}_{\mathrm{S}}+\left[\mathrm{Si}(\mathrm{OH})_{4}\right]}
$$

to the data from each ${ }^{30} \mathrm{Si}$ enrichment series. The kinetic parameters $V_{\max }$ and $K_{s}$, and their $95 \%$ confidence limits, were calculated by the nonlinear regression method of Wilkinson (1961)

\section{RESULTS}

The specific uptake rate of silicic acid (V) is plotted as a function of $\left[\mathrm{Si}(\mathrm{OH})_{4}\right]$ in Fig. 1. It is clear that $\mathrm{V}$ increased with increasing silicic acid concentration in ring 81-D in September/October (Fig. 1a) and again in ring $82-\mathrm{B}$ in June (Fig. $1 \mathrm{C}$ ) when ambient silicic acid

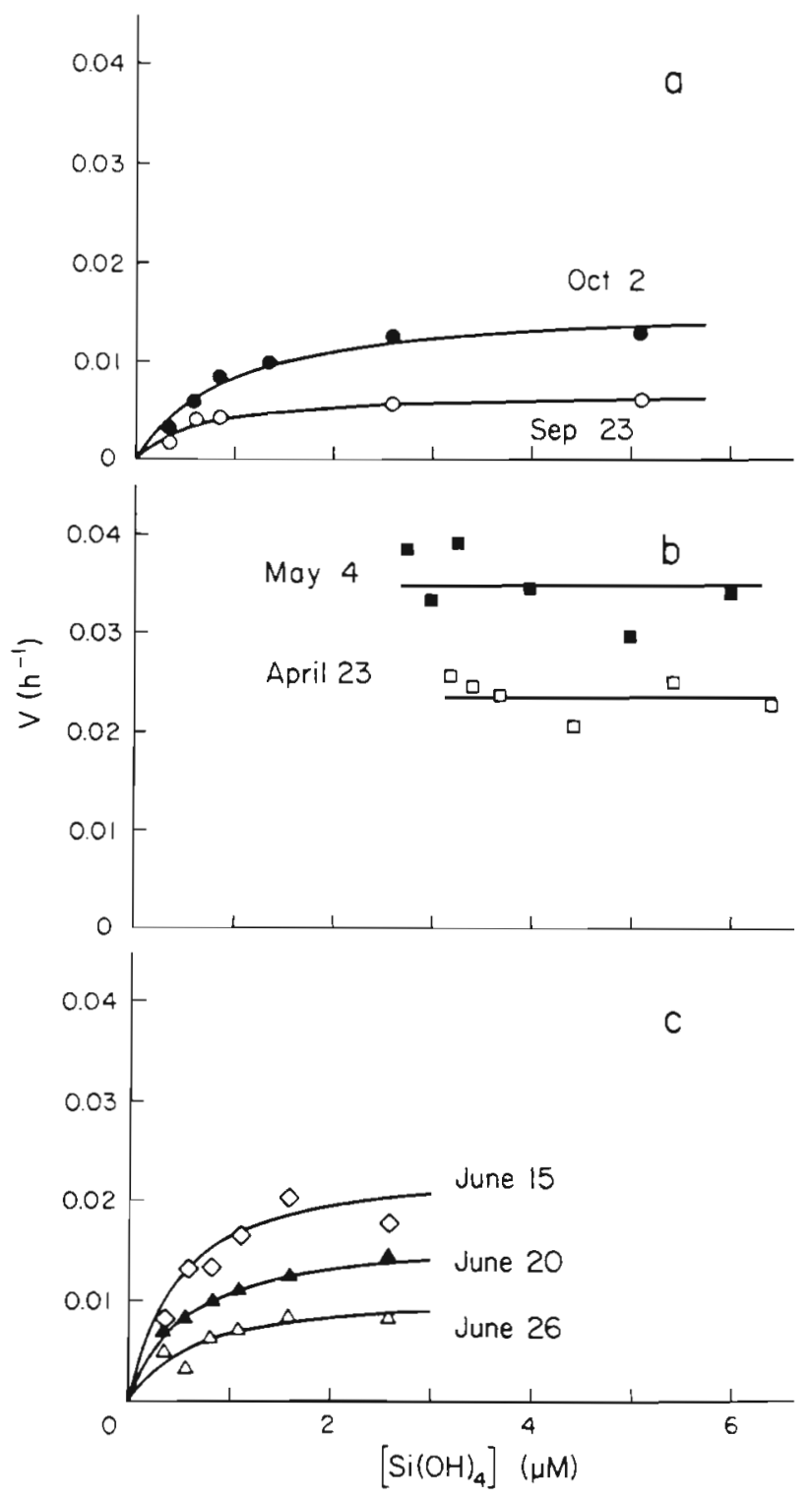

Fig. 1. Specific uptake rate of silicic acid, $V$, plotted as a function of the extracellular silicic acid concentration $\left[\mathrm{Si}(\mathrm{OH})_{4}\right]$ for natural phytoplankton assemblages sampled within $26 \mathrm{~km}$ of the centers of Gulf Stream warm-core rings. (a) Ring 81-D in September/October; (b) ring 82-B in April/ May; (c) ring 82-B in June. (a) and (c): data from locations at which silicic acid was undetectable by conventional methods $(<0.2 \mu \mathrm{M})$. Uptake rates were calculated and plotted against $\left[\mathrm{Si}(\mathrm{OH})_{4}\right]$ using an assumed ambient $\left[\mathrm{Si}(\mathrm{OH})_{4}\right]$ of $0.1 \mu \mathrm{M}$. Curves plotted in (a) and (c) are the fitted Michaelis-Menten hyperbolas for which the kinetic parameters $V_{\max }$ and $K_{\mathrm{s}}$ are presented in Table 1

concentrations were $<0.2 \mu \mathrm{M}$. This response indicates that the rate of silicic acid uptake by the diatom assemblage was limited by the low substrate concentrations that prevailed at those times. In ring $82-\mathrm{B}$ in April/May there is no evidence that increasing the silicic acid concentration above its in situ level 
increased the rate of uptake (Fig. 1b). Thus the 2.5 to $2.9 \mu \mathrm{M}$ concentrations present in the surface layer from April 23 to May 3 were sufficient to permit most or all of the diatoms present to take up silicic acid at their maximal rates. Calculated $V_{\max }$ values ranged from $0.0067 \mathrm{~h}^{-1}\left(0.23\right.$ doublings $\left.\mathrm{d}^{-1}\right)$ in ring $81-\mathrm{D}$ on September 23 to $0.0348 \mathrm{~h}^{-1}\left(1.21\right.$ doublings $\left.\mathrm{d}^{-1}\right)$ in ring 82 $\mathrm{B}$ on May 4 (Table 1). These $V_{\max }$ values represent conservative estimates of the maximum silica doubling rates attainable by the living diatoms because any suspended mineral silicates or nonliving siliceous debris would cause the $\mathrm{V}$ measured in a tracer experiment to underestimate the doubling rate of the living siliceous cells (Goering et al. 1973). Calculated halfsaturation constants $\left(K_{\mathrm{s}}\right)$ are subject to statistical uncertainties ranging from \pm 40 to $\pm 100 \%$ at the $95 \%$ confidence level (Table 1) but $K_{\mathrm{s}}$ was $\leq 0.9 \mu \mathrm{M}$ in all cases in which the uptake rate was detectably substrate-limited. In ring 82-B during April and early May, when the ambient silicic acid concentration was high enough to support uptake at maximal rates, the $\mathrm{K}_{\mathrm{s}}$ for uptake is known to be considerably lower than the ambient concentration of 2.5 to $2.9 \mu \mathrm{M}$, but is otherwise undefined (Goering et al. 1973).

\section{DISCUSSION}

The general physical, chemical and biological conditions that prevailed in rings $81-\mathrm{D}$ and $82-\mathrm{B}$ when our experiments were performed have been described elsewhere (e.g. Fox et al. 1983, 1984a,b, Ducklow \& Hill

Table 1 Kinetic parameters for silicic acid uptake by the natural phytoplankton assemblages at the center of Gulf Stream warm-core ring 81-D in September/October, and ring $82-B$ in April/May and June. See Fig. 1 for the actual $V$ versus $\left[\mathrm{Si}(\mathrm{OH})_{4}\right]$ curves. Values of $\mathrm{V}_{\max }$ and $\mathrm{K}_{\mathrm{s}}$ for ring $81-\mathrm{D}$ in September/October and $82-B$ in June were calculated by the nonlinear regression method of Wilkinson (1961). For ring 82 $B$ in April/May, when no kinetic response was evident, $K_{b}$ is unknown and $V_{\text {max }}$ is the mean of the 6 measured values of $V$ All \pm entries denote the $95 \%$ confidence interval

\begin{tabular}{|ccc|}
\hline & $\begin{array}{c}V_{\max } \\
\left(\mathrm{h}^{-1}\right)\end{array}$ & $\begin{array}{c}K \\
(\mu \mathrm{M})\end{array}$ \\
\hline Ring 81-D & & \\
Sep 23 & $0.0067( \pm 0.0021)$ & $0.53( \pm 0.55)$ \\
Oct 2 & $0.0158( \pm 0.0035)$ & $0.90( \pm 0.56)$ \\
Ring 82-B & & - \\
Apr 23 & $0.0237( \pm 0.0041)$ & - \\
May 4 & $0.0348( \pm 0.0037)$ & $0.56( \pm 0.58)$ \\
Jun 15 & $0.0238( \pm 0.0084)$ & $0.57( \pm 0.22)$ \\
Jun 20 & $0.0169( \pm 0.0022)$ & \\
Jun 26 & $0.0110( \pm 0.0031)$ & $0.66( \pm 0.50)$ \\
\hline
\end{tabular}

1985, Garside 1985, Hitchcock et al. 1985, Joyce \& Stalcup 1985, Nelson et al. 1985, 1989). The conditions of greatest direct importance in interpreting our results were: (1) Silicic acid, nitrate and phosphate were depleted to colorimetrically undetectable concentrations $(<0.2,0.1$ and $0.05 \mu M$, respectively) in the surface layer of ring 81-D in September/October (Fox et al. 1983); (2) In April, ring 82-B had recently undergone deep convective mixing (Joyce \& Stalcup 1985) and silicic acid concentrations were vertically uniform at 2.5 to $2.9 \mu \mathrm{M}$ throughout the upper $300 \mathrm{~m}$. Nitrate and phosphate were also vertically uniform at concentrations of 5.1 and $0.25 \mu \mathrm{M}$, respectively (Fox et al. 1984a); (3) Ring 82-B became thermally stratified some time in May and was strongly stratified by mid June (Evans et al. 1985, Nelson et al. 1985). Silicic acid, nitrate and phosphate were all depleted to colorimetrically undetectable levels throughout the surface layer (Fox et al. 1984b) although a much more sensitive chemiluminescent analysis showed nitrate to be present at $>10 \mathrm{nM}$ at all times (Garside 1985)

Fig. 1a, c presents the first data on the concentration dependence of silicic acid uptake by natural diatom assemblages residing in a surface layer in which ambient silicic acid concentrations had been depleted to levels below the detection limit of conventional analyses. When the uptake rate of any nutrient is measured in an isotopic tracer experiment and that rate plotted as a function of the extracellular nutrient concentration, analytical uncertainties in the concentration of unlabelled substrate affect the position of each datum along both the ordinate and the abscissa. Thus, the undetectable 10 to $0.2 \mu \mathrm{M}$ ) siljcic acid concentrations present in September, October and June introduce uncertainties into the $\mathrm{V}$ vs $\left[\mathrm{Si}(\mathrm{OH})_{4}\right]$ data that are not present when the ambient concentration is readily measurable. The effect on $\mathrm{V}$ is proportional to the analytical uncertainty in the unlabelled ambient concentration, divided by the total (ambient plus added label) concentration at which the experiment is performed (Brzezinski \& Nelson 1989). Thus in our experiments performed at undetectable ambient concentrations, where $\left[\mathrm{Si}(\mathrm{OH})_{4}\right]$ is known only to have been between 0 and $0.2 \mu \mathrm{M}$ and assigned a value of $0.1 \pm$ $0.1 \mu \mathrm{M}$ for calculating $\mathrm{V}$, this uncertainty ranges from a minimum of $\pm 2 \%( \pm 0.1 / 5.1)$ at tracer additions of 5.0 $\mu \mathrm{M}$ to a maximum of $\pm 29 \%( \pm 0.1 / 0.35)$ at the lowest (0.25 uM) additions.

Fig. 2 presents the $V$ vs $\left[\mathrm{Si}(\mathrm{OH})_{4}\right]$ curves obtained from our June 20 station at the center of ring $82-B$, plotted assuming that the true ambient silicic acid concentration was $0,0.1$ and $0.2 \mu \mathrm{mM}$, respectively. While the presence of substrate limitation is clear qualitatively, and the general range of limiting concentrations defined in all 3 curves, the true shape of the $\mathrm{V}$ vs $\left[\mathrm{Si}(\mathrm{OH})_{4}\right]$ response is uncertain within the limits 


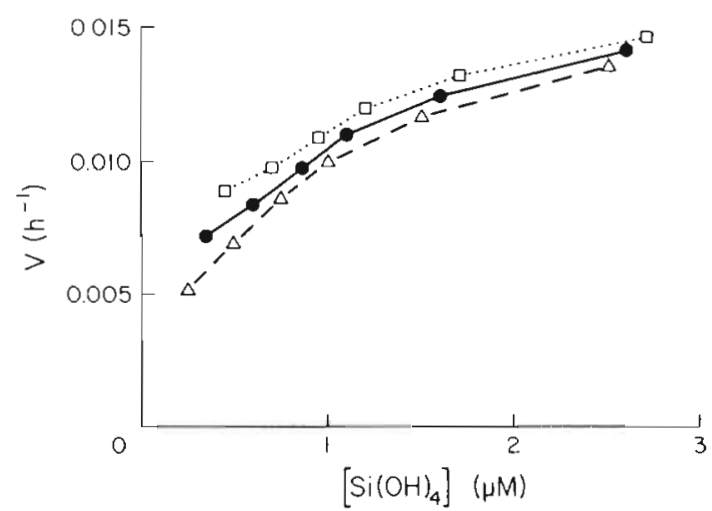

Fig. 2. Uptake kinetic data for the center of ring 82-B on June 20 calculated assuming that the ambient silicic acid concentration was $0.0 \mu \mathrm{M}(\dot{)}), 0.1 \mu \mathrm{M}(\bullet)$ and $0.2 \mu \mathrm{M}(\square)$. Silicic acid was undetectable in the surface layer at this station to a method whose limit of detection was $0.2 \mu \mathrm{M}$ (Fox et al. 1984b)

shown. This ambiguity translates into uncertainties of less than $5 \%$ in the value of $V_{\text {max }}$, but greater uncertainties in $\mathrm{K}_{\mathrm{s}}$. We refitted each kinetic curve using assumed ambient silicic acid concentrations of $0,0.1$ and $0.2 \mu \mathrm{M}$ (values in Table 1 are based on the midrange assumption of $0.1 \mu \mathrm{M})$. The resulting uncertainty in $K_{s}$ ranges from $\pm 9 \%$ in ring $82-B$ on June 26 to $\pm 25 \%$ in the same ring on June 20 (the case shown in Fig. 2). In all cases the uncertainty in $K_{\mathrm{s}}$ resulting from the fact that the ambient $\left[\mathrm{Si}(\mathrm{OH})_{4}\right]$ was undetectable is considerably less than the statistical uncertainty in $\mathrm{K}_{\mathrm{s}}$ at any one assumed ambient concentration.

The time course of $\mathrm{V}_{\max }$ for the diatom assemblage at the center of ring 82-B between April 23 and June 26 is shown in Fig. 3. The value of $V_{\max }$ increased by $47 \%$ between April 23 and May 4, a period that coincided with the onset of seasonal stratification (Evans et al. 1985). In the severely nutrient-depleted surface layer that was present on June $15, V_{\text {max }}$ was approximately the same as that measured on April 23; it then decreased by more than $50 \%$ between June 15 and 26 .
Because $V_{\text {max }}$ is a measure of the highest rates of silicic acid uptake that each diatom assemblage could achieve in the absence of silicon limitation, the observed temporal trend has at least 3 possible explanations:

(1) Diatom species successions. It is possible that the relative abundance of diatoms with higher maximal rates of growth and silicon uptake increased between April 23 and May 4 as the water column stratified and conditions favorable for a phytoplankton bloom developed. Then as nutrients became depleted in the surface layer the diatom species assemblage may have changed to one dominated by species with lower maximum uptake rates. It is known that the dominant diatom species over the late April-early May period were very small ( 3 to $6 \mu \mathrm{m}$ ) centric forms, including Minidiscus trioculatus and Thalassiosira cf. bulbosa, and that these were replaced by Leptocylindrus danicus and Chaetoceros cf. vixvisibilis by June 15 (Gould \& Fryxell 1988a,b). However, we have no independent measure of $\mathrm{V}_{\max }$ or $\mathrm{K}_{\mathrm{s}}$ for any of these species. It is highly unlikely that the $>50 \%$ decrease in $V_{\max }$ between June 15 and 26 resulted from a species succession, as the diatom species composition at the center of ring $82-\mathrm{B}$ remained nearly constant over that period (Gould \& Fryxell $1988 \mathrm{a}, \mathrm{bj}$.

(2) Limitation by other nutrients. The experiments reported here were performed by adding ${ }^{30} \mathrm{Si}$-labelled silicic acid at a series of enrichments over the ambient concentration while all other nutrients remained at ambient levels. In addition to silicic acid, nitrate and phosphate were depleted from readily measurable levels (5.1 and $0.25 \mu \mathrm{M}$, respectively) at ring center on May 4 to colorimetrically undetectable levels $(<0.1$ and $<0.05 \mu \mathrm{M}$, respectively) on June 15 (Fox et al. 1984a,b). In addition, a much more sensitive chemiluminescent analysis indi-
Fig. 3. Calculated maximum specific uptake rates of silicic acid $\left(V_{\text {max }}\right)$ by the natural phytoplankton assemblage at the center of ring $82-\mathrm{B}$ on 5 sampling dates between April 23 and June 26. Error bars represent $95 \%$ confidence intervals

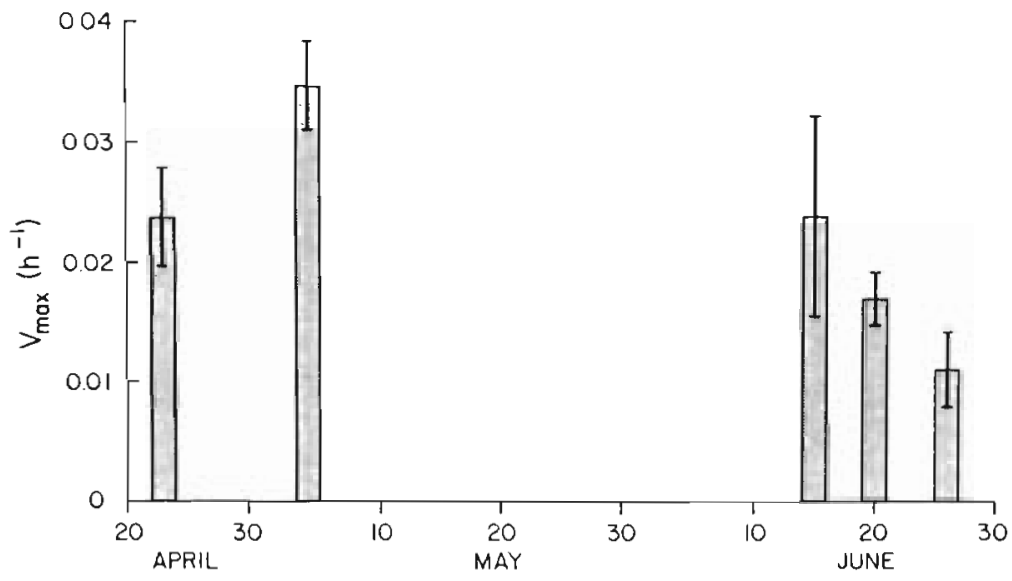


cated that near-surface nitrate concentrations decreased from ca 40 to $60 \mathrm{nM}$ on June 15 to 20 to $30 \mathrm{nM}$ on June 24 (Garside 1985). It is not known whether these mutrient concentrations limited the growth rates of the diatoms present within the ring. However, the relatively tight coupling between silicic acid uptake and cell division (e.g. Darley et al. 1976, Sullivan 1977, Chisholm et al. 1978) means that $\mathrm{N}$ limitation, $\mathrm{P}$ limitation or any other factor that diminished the division rates of diatoms in situ could also be expected to have decreased the maximal (i.e. substrate-unlimited) rate of silicic acid uptake.

(3) Siliceous detritus. Any nonliving siliceous material present during a ${ }^{30} \mathrm{Si}$ incubation experiment causes the measured value of $\mathrm{V}$ to be lower than that which characterizes the living diatom cells (Goering et al. 1973). Thus any change with time in the relative abundances of living and nonliving siliceous particles would cause the measured value of $V_{\text {max }}$ to change independently of any changes in the true $V_{\text {max }}$ of the living diatom cells. In rings 81 $D$ in September/October and $82-B$ in June, the suspended particulate silica in the surface layer was ca $90 \%$ biogenic (Nelson et al. 1982, Brzezinski \& Nelson 1989). Direct microscopic examination indicated that 90 to $95 \%$ of the recognizable siliceous particles were physically intact, apparently living, diatoms in ring 81-D during September/October and ring 82-B during April/May (Fryxell et al. 1985, Gould \& Fryxell 1988a) but that this figure dropped to $69 \%$ in ring $82-B$ during June (Gould \& Fryxell 1988a). The larger proportion of detrital biogenic silica in June is great enough to account for the generally lower $V_{\text {max }}$ values measured during that month. However, it cannot explain the decrease in $V_{\max }$ with time during June, as there is no evidence that detrital silica was accumulating during that period (Gould \& Fryxell 1988a).

Previously measured $K_{\mathrm{s}}$ values for silicic acid uptake by natural diatom assemblages range from $1.5 \mu \mathrm{M}$ in Baja California coastal waters (Azam \& Chisholm 1976) to $3.7 \mathrm{MM}$ in an upwelling plume off Peru (Nelson et al. 1981), with an overall mean of $2.65 \mu \mathrm{M}$. Thus the lowest previously reported value is $67 \%$ higher than the highest $K_{\mathrm{s}}$ we measured in either ring (Table 1) and over twice as great as the mean of all values from rings 81-D and $82-\mathrm{B}(0.64 \mu \mathrm{M})$. The mean $\mathrm{K}_{\mathrm{s}}$ value for the rings is less than one fourth of the mean value reported from other lcoations.

Reported $K_{s}$ values for silicic acid uptake by individual diatom species in culture studies range from 0.3 to 22 uM (data from various sources, summarized by Nelson in press). Even if the exceptionally high $\mathrm{K}_{\mathrm{s}}$ values reported by Jacques (1983) for 2 Antarctic species are discounted as being uncharacteristic of diatoms from other areas, the mean $K_{s}$ for the remaining (i.e. temperate and warm-water) species is $2.3 \mu \mathrm{M}$, or 3.5 times the mean of $\mathrm{K}_{\mathrm{s}}$ values we measured in rings $81-\mathrm{D}$ and $82-\mathrm{B}$. The previous kinetic studies of silicic acid uptake by diatoms have given greatest emphasis to eutrophic nearshore waters and their resident flora; thus the higher affinity for silicon exhibited by diatoms in rings $81-\mathrm{D}$ and $82-\mathrm{B}$ may be more representative of the silicon uptake kinetics of diatoms in oligotrophic central-ocean habitats

The results we report here show clearly that a significant fraction, and perhaps all, of the diatoms present in ring 81-D in September and early October and 82-B in mid to late June were experiencing silicon limitation as it pertains to the incorporation of the element into siliceous hard parts. Our results are just as clear in showing the absence of silicon limitation for at least the bulk of the diatom assemblage in ring 82-B in April and early May. However, not even our September, October and June data are sufficient to demonstrate conclusively that the growth or division rates of diatoms in rings $81-\mathrm{D}$ and $82-\mathrm{B}$ were limited by silicon at those times. It is possible for a diatom to continue dividing at a nearly maximal rate, even when its rate of silicic acid uptake is clearly limited by substrate availability, by the simple response of producing a thinner frustule; the experimentally observed fact is that substantially lower concentrations of silicic acid are often required to limit a diatom's division rate than to limit its rate of silicic acid uptake (e.g. Guillard et al. 1973, Paasche 1973a,b, Nelson et al. 1976). Chemostat studies of a clone of Thalassiosira rotula isolated from ring $82-\mathrm{B}$ in April show that its division rate was severely silicon-limited at all extracellular silicic acid concentrations below $0.25 \mu \mathrm{M}$ (Brzezinski 1987). However by mid June $T$. rotula was rare, and confined to relatively nutrient-rich waters within and beneath the seasonal thermocline, in ring 82-B (Brzezinski 1987). Thus the status of silicon as a division-rate limiting nutrient for those diatoms that were abundant within the nutrient-depleted surface layer of rings 81-D and 82-B remains uncertain, even though their rate of silicic acid uptake was clearly limited by substrate availability.

One common response of phytoplankton cells to nutrient limitation is an increase in sinking rate, and diatoms appear to be particularly sensitive to silicon limitation in this regard (e.g. Smayda 1970, Bienfang et al. 1982, Harrison et al. 1986). The clear evidence of silicon limitation (at least with respect to uptake) in the centers of 2 Gulf Stream warm-core rings raises the possibility that the sinking of silicon-limited cells out of the photic zone may play a significant role in both the silicon cycle and diatom species competition within these systems. We have no information on the vertical. 
flux of biogenic particulate silica, or on the sinking rate of any diatom species within the 2 rings we examined. However, natural assemblages dominated by either Leptocylindrus danicus or Chaetoceros $\mathrm{sp}$. have an unusually pronounced ability to keep their sinking rates low when experiencing silicon limitation (Bienfang \& Harrison 1984). L. danicus and a Chaetoceros species (C. vixvisibilis or a morphologically similar form) were the 2 overwhelmingly dominant diatom species in the interior of ring 82-B throughout June (Gould \& Fryxell 1988a), a period when our kinetic data provide direct evidence of silicon limitation. It remains possible that this is a coincidence, but the June diatom assemblage very closely resembles that which one might predict from previous studies if sinking under silicon limitation were playing a major role in determining the outcome of diatom species competition in this ring.

The high affinity (low $\mathrm{K}_{\mathrm{s}}$ ) for silicic acid exhibited by the diatom assemblages in both rings could give them a competitive advantage when competing for low concentrations of silicic acid. To quantify this advantage, however, we need information on both $\mathrm{K}_{\mathrm{s}}$ and $\mathrm{V}_{\max }$ as a species with a high enough $V_{\max }$ can outcompete other species at low substrate concentrations even if its competitor has a significantly lower $K_{s}$ (e.g. Healey 1980). The mean of all $V_{\max }$ values we measured for diatom assemblages in rings $81-\mathrm{D}$ and $82-\mathrm{B}$ is $0.022 \mathrm{~h}^{-1}$ (which is equivalent to 0.76 doublings $\mathrm{d}^{-1}$ ) and the mean $\mathrm{K}_{\mathrm{s}}$ is $0.64 \mu \mathrm{M}$. Our measured $\mathrm{V}_{\max }$ values must underestimate the true $V_{\max }$ of the living cells because of the effect of siliceous detritus, and this underestimate may have been as great as 30 to $50 \%$ in. June (see above). Measured $K_{\mathrm{s}}$ values are insensitive to detrial effects. The relative advantage of a low $K_{\mathrm{s}}$ can be evaluated by considering 2 species with kinetic constants $V_{\max 1}, K_{s 1}$ and $V_{\max 2}, K_{\mathrm{s} 2}$ respectively. The 2 species will have equal uptake rates when:

$$
\frac{V_{\max 1}}{V_{\max 2}}=\frac{K_{\mathrm{s} 1}+\left(\mathrm{Si}(\mathrm{OH})_{4}\right]}{K_{\mathrm{s} 2}+\left[\mathrm{Si}(\mathrm{OH})_{4}\right]}
$$

At silicic acid concentrations lower than that which satisfies Eq. (2) the species with the lower $\mathrm{K}_{\mathrm{s}}$ will have the higher uptake rate; at higher silicic acid concentrations the species with the higher $V_{\max }$ will. Even if we use the very conservative $V_{\max }$ value of $0.022 \mathrm{~h}^{-1}$ as typical of diatoms within the rings, then according to Eq. (2) a species with a $\mathrm{K}_{\mathrm{s}}$ equal to the mean value measured for natural diatom assemblages outside of warm-core rings $(2.65 \mu \mathrm{M})$ must have a $V_{\max }$ of at least $0.075 \mathrm{~h}^{-1}$ before its uptake rate at $0.2 \mu \mathrm{M} \mathrm{Si}(\mathrm{OH})_{4}$ would be expected to equal or exceed that of the rings assemblages. If the ambient $\left[\mathrm{Si}(\mathrm{OH})_{4}\right]$ is taken to be in the mid range of the 0 to $0.2 \mu \mathrm{M}$ uncertainty imposed by the analytical detection limit (i.e. $0.1 \mu \mathrm{M}$ ), the necessary $\mathrm{V}_{\max }$ increases to $0.082 \mathrm{~h}^{-1}$. Three very rapidly growing diatoms isolated from coastal waters, Thalassiosira pseudonana, Chaetoceros debilis and Skeletonema costatum, have been reported to have silicon $V_{\max }$ values $>0.075 \mathrm{~h}^{-1}$ (Nelson et al. 1976, Conway \& Harrison 1977), but a considerably greater number do not (e.g. Paasche 1973b. Nelson et al. 1976). In addition, some high-latitude diatoms apparently have such high $\mathrm{K}_{\mathrm{S}}$ values for silicon ( $\geq 12 \mu \mathrm{M}$; Jacques 1983) that a completely unrealistic $V_{\text {max }}\left(>0.32 \mathrm{~h}^{-1}\right)$ would be needed for successful competition at $\left[\mathrm{Si}(\mathrm{OH})_{4}\right] \leq 0.2 \mu \mathrm{M}$.

Several of the diatom species whose silicon uptake kinetics have been examined in culture have an apparent threshold concentration of silicic acid below which net uptake (uptake in excess of the rate of loss of silica by dissolution) does not occur. When present, this threshold is usually between 0.2 and $0.4 \mu \mathrm{M}$ (Paasche 1973b, Conway \& Harrison 1977), indicating that those diatoms that exhibit a threshold response would be incapable of long-term survival at the $<0.2 \mu \mathrm{M}$ silicic acid concentrations that typified ring $81-\mathrm{D}$ in September/October and 82-B in June. Rates of silica dissolution measured in the surface waters of ring $82-B$ in June did frequently exceed measured rates of uptake, but it is likely that much of that dissolution was coming from empty frustules and shell fragments rather than from the living cells (Brzezinski \& Nelson 1989). Thus the living diatoms could still have had the positive net silica balance needed for long-term survival.

The comparisons made above between the silicon uptake kinetics observed in diatom assemblages in Gulf Stream warm-core rings and those of individual diatom species that have been examined in culture presuppose that the low silicic acid concentrations in the surface water of the ring approximate steady-state values. This approximation appears to be reasonably accurate for ring $82-B$ during June, when concentrations $>0.2 \mu \mathrm{M}$ were never observed. However, surface concentrations as high as $0.7 \mu \mathrm{M}$ were occasionally recorded in the interior of ring 81-D in September (Fox et al. 1983), indicating pulsed injections of silicic acid, and there is now evidence that the near-surface waters of warmcore ocean eddies may typically receive stronger episodic nutrient injections than do their environs: during June the interior of ring 82-B was the site of a localized, axially symmetrical maximum in phytoplankton biomass which contained a much higher proportion of diatoms than did the phytoplankton in the surrounding Slope Water (Nelson et al. 1985). It now appears that this ring-center phytoplankton maximum was sustained by upwelling within the ring interior that resulted from the ring's frictional loss of energy with time (Nelson et al. 1989). This process increased the magnitude of winddriven pulses of nutrients from below by greatly decreasing the potential energy barrier between the sea surface and the nutricline, and was transporting both 
silicic acid and nitrate upward at rates approximately equal to their measured net rates of uptake by the phytoplankton within the ring in June (Nelson et al. 1989). Thus, although the surface layers of both the ring and the surrounding Slope Water had silicic acid and nitrate concentrations that were indetectable by conventional analyses, the time-integrated vertical supply rates of both nutrients were considerably higher inside than outside the ring.

When pulsed injections cause nutrient concentrations in surface waters to be elevated significantly for restricted periods of time the ability of the cells to exploit those pulses can become a complex response to several temporally changing variables. For ammonium (the nutrient that has received the most attention to date with respect to transient responses by the phytoplankton) this ability is known to be influenced by the magnitude and duration of the pulse (e.g. Quarmby et al. 1982), the mutritional status of the cells before the nutrient injection (e.g. Goldman \& Glibert 1982) and the timing of the pulse with respect to the day: night cycle (Olson \& Chisholm 1983, Wheeler et al. 1983). It has also been shown for pulsed ammonium injections that transient responses of this kind can alter the outcome of long-term competition between diatoms that inhabit warm-core rings (Brzezinski \& Nelson 1988). Nelson et al. (1976) did not observe enhanced uptake rates of pulses of silicic acid by Si-starved versus Sireplete cells of 2 species of Thalassiosira (now recognized as $T$. pseudonona and $T$. oceanica); however, the applicability of the rest of these findings to episodic injections of silicic acid is uncertain. In the simple case where competition for a pulse of silicic acid is governed by the kinetic constants, a competitor with a $\mathrm{K}_{\text {s }}$ value typical of temperate species $(2.3$ to $2.65 \mu \mathrm{M})$ would require a $V_{\max } 3$ to 4 times that of the ring diatom assemblage in order to acquire the majority of a pulse of silicic acid when the maximum [Si(OH) $)_{4}$ ] resulting from the pulse is $\leq 1.3 \mu \mathrm{M}$ (Fig. 4 ). This value represents a 1:1 mixture of nutrient-depleted surface water with that below the seasonal thermocline in ring $82-B$, and is about twice the maximum pulse size actually observed in these rings $(0.7 \mu \mathrm{M} \text { in ring } 81-\mathrm{D})_{i}$ it may thus represent a reasonable upper limit for pulsed injections of silicic acid in warm-core rings.

It is not yet known whether the low $K_{s}$ values for silicic acid uptake measured in Gulf Stream warm-core rings represent a specialized response to the rather unusual nutrient supply processes that operate there or are reasonably typical of diatoms in oligotrophic surface waters. If diatoms in large nutrient-depleted areas such as the Sargasso Sea or the tropics typically have $K_{\mathrm{S}}$ values for silicic acid in the area of $0.6 \mu \mathrm{M}$, then those waters may be relatively silicon-rich environments for the diatoms that reside there. This would imply that

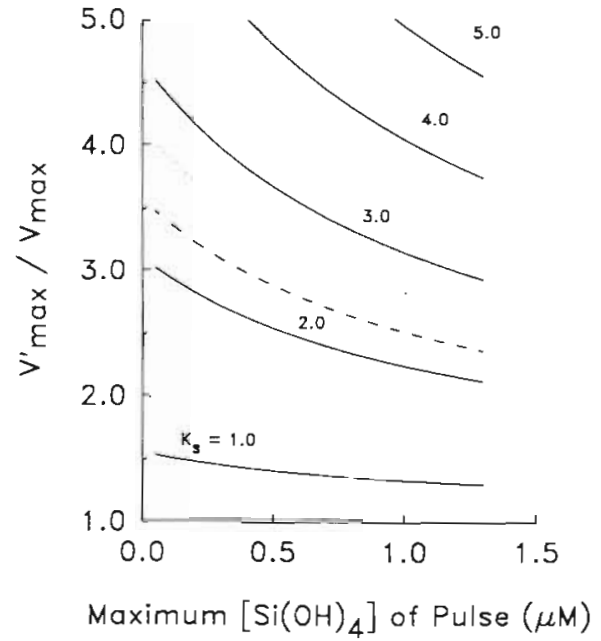

Fig. 4. Results of a numerical simulation of the competition between 2 diatom species for a pulsed injection of silicic acid. Solid curves represent ratio of maximum uptake rate of a competing species to that of the ring diatom assemblage $\left(V_{\text {max }}^{\prime} / V_{\text {max }}\right)$ which permits the competitor and the ring assemblage to take up equal portions of a nutrient pulse ranging from 0.05 to $1.3 \mu \mathrm{M}$. Each curve corresponds to a different $K_{\mathrm{s}}$ of the competitor species, ranging from 1.0 to 5.0 $\mu \mathrm{M}$ as shown. Dashed and dotted curves represent the outcome of this simulation for species with $K_{\mathrm{s}}$ values equal to the mean of reported values from culture experiments $(2.3 \mu \mathrm{M})$ and the mean for natural assemblages from coastal habitats $(2.65 \mu M)$, respectively. All curves were constructed using the numerical simulation of competition for nutrient pulses described by Brzezinski \& Nelson (1988), with $\mathrm{K}_{\mathrm{s}}$ and $\mathrm{V}_{\max }$ for the ring assemblage held constant at $0.64 \mu \mathrm{M}$ and $0.022 \mathrm{~h}^{-1}$, respectively. The model is insensitive to the value of $V_{\max }$ used

while silicon availability can play a major role in controlling the species composition of the diatom assemblages in such habitats, it may be much less important in limiting the overall diatom abundance.

Acknowledgements. We thank Julie A. Ahern for her very capable assistance in the isotope sample preparations and data processing. Hugh W. Ducklow, Gary L. Hitchcock, Christopher Langdon and James J. McCarthy worked with us in collecting the samples at sea, and discussions with them during and after the cruises provided valuable insights into biological processes in warm-core rings. Terrence $M$. Joyce explained the vertical circulation and mixing regimes in ring $82-B$ to us in a way that made their implications for nutrient supply rates readily apparent. Paul J. Treguer provided several helpful comments on an earlier draft of this paper Financial support was provided by the National Science Foundation, through grants \#OCE8017269 and OCE-8510835 to Oregon State University.

\section{LITERATURE CITEIP}

A.nderson, L. Dyrssen, D. (1981). Chemical constituents of the Arctic Ocean in the Svalbard area. Oceanol. Acta 4: 305-311

Azam, F., Chisholm, S. W. (1976). Silicic acid uptake and incorporation by natural marine phytoplankton populations. Limnol. Oceanogr. 21: 427-433 
Bainbridge, A. E (1980). GEOSECS Atlantic expedition, Vol. 2. Sections and profiles. U.S. Government Printing Office, Washington

Bienfang, P. K., Harrison, P. J. (1984). Sinking rate response of natural assemblages of subtropical phytoplankton to nutrient depletion. Măr. Biol. 83: 293-300

Blenfang, P. K., Harrison, P. J., Quarmly, L. M. (1982). Sinking rate response to depletion of nitrate, phosphate and silicate in four marine diatoms. Mar. Biol. 67: 295-302

Brzezinski, M. A. (1985). The Si:C:N ratio of marine diatoms. Interspecific variability and the effect of some environmental variables. J. Phycol. $21 \quad 347-357$

Brzezinski, M. A. (1987). Physiological and environmental factors affecting diatom species competition in a Gulf Stream warm-core ring. $\mathrm{Ph}$. D. dissertation, Oregon State University, Corvallis

Brzezinski, M. A., Nelson, D. M. (1988). Interactions between pulsed nutrient supplies and photocycles affect phytoplankton competition for limiting nutrients in long-term culture. J. Phycol. 24: 346-356

Brzezinski, M. A., Nelson, D. M. (1989). Seasonal changes in the silicon cycle within a Gulf Stream warm-core ring Deep Sea Res. 36: 1009-1030

Chisholm, S. W., Azam, F., Eppley, R. W. (1978). Silicic acid incorporation in marine diatoms on light: dark cycles: use as an assay for phased cell division. Limnol. Oceanogr. 23 $518-529$

Conway, H. L., Harrison, P. J. (1977). Marine diatoms grown in chemostats under silicate or ammonium limitation. IV Transient response of Chaetoceros debilis, Skeletonema costatum and Thalassiosira gravida to a single addition of the limiting nutrient. Mar Biol. 43: 33-43

Cooper, L. H. N. (1933). Chemical constituents of biological importance in the English Channel. Pt. I. Phosphate, silicate, nitrate, nitrite, ammonia. J. mar biol. Ass. U.K. 18: $677-728$

Darley, W. M., Sullivan, C. W., Volcani, B. C. (1976). Studies of the biochemistry and fine structure of silica shell formation in diatoms: division cycle and chemical composition of Navicula pelliculosa during light:dark synchronized growth. Planta 130: 159-167

Ducklow, H. W. Hill, S. M. (1985). Tritiated thymidine incorporation and the growth of heterotrophic bacteria in warm core rings. Limnol. Oceanogr. 30: 260-272

Dugdale, R. C. (1967). Nutrient limitation in the sea: dynamics, identification and significance. Limnol. Oceanogr 12: 685-695

Dugdale, R. C., Goering, J. J. (1970). Nutrient limitation and the path of nitrogen in Peru Current production. Anton Bruun Rep. \#4. Texas A\&M Press

Evans, R. H., Baker, K. S., Brown, O. B., Smith, R. C. (1985). Chronology of warm-core ring 82-B. J. geophys. Res. 40: 8803-8811

Fox, M. F., Bates, P. P., Kester, D. R. (1983). Nutrient data from warm-core ring 81-D from R/V ATLANTIS II cruise 110. Tech. Rep. \#83-3, Univ. of Rhode Island

Fox, M. F., Bates, P. P., Kester, D. R. (1984a). Nutrient data from warm-core ring 82-B from R/V KNORR cruise 93. Tech. Rep. \#84-1, Univ. of Rhode Island

Fox, M. F., Bates, P. P., Kester, D. R. (1984b). Nutrient data from waml-core ring 82-B from R/V KNORR cruise 95. Tech. Rep. \#84-2, Univ. of Rhode Island

Fryxell, G. A., Gould, R. W Jr, Balmori, E. R., Theriot, E. C. (1985). Gulf Stream warm-core rings: phytoplankton in two fall rings of different ages. J. Plankton Res. 7: 339-364

Garside, C. (1985). The vertical distribution of nitrate in open ocean surface water. Deep Sea Res. 32: 723-732
Goering, J. J., Nelson, D. M., Carter, J. A. (1973). Silicic acid uptake by natural populations of marine phytoplankton. Deep Sea Res. 20 (9): 777-789

Goldman, J. C., Glibert, P. M. (1982). Comparative rapid ammonium uptake by four species of marine phytoplankton. Linmol. Oceanogr 27:814-827

Gould, R. W. Fryxell, G. A. (1988a). Phytoplankton species composition and abundance in a Gulf Stream warm core ring. I. Changes over a five month period. J. mar Res. 46: $367-398$

Gould, R. W., Fryxell, G. A. (1988b). Phytoplankton species composition and abundance in a Gulf Stream warm-core ring. II. Distributional patterns. J mar. Res. 46: 399-428

Guillard, R. R. L., Kilham, P. (1977). The ecology of marine planktonic diatoms. In: Werner, D. (ed.) The biology of diatoms. Univ. of California Press, Berkeley, p. 372-469

Guillard, R. R. L., Kilham, P., Jackson, T. A. (1973). Kinetics of silicon limited growth in the marine diatom Thalassiosira pseudonana. Hasle and Heimdal (Cyclotella nana Hustedt). J. Phycol. 9: 233-237

Harrison, P. J., Turpin, D. H., Bienfang, P. K., Davis, C. O. (1986). Sinking as a factor affecting phytoplankton species succession: the use of selective loss semi-continuous cultures. J. exp. mar. Biol. Ecol. 99: 19-30

Healey, F. P. (1980). Slope of the Monod equation as an indicator of advantage in nutrient competition. Microb. Ecol. 5: 281-286

Hitchcock, G. L., Langdon, C., Smayda, T J. (1985). Seasonal variations in phytoplankton biomass in a warm-core Gulf Stream ring. Deep Sea Res. 32: 1287-1300

Hooker, S. B., Olson, D. B. (1985). Center of mass estimation in closed vortices: a verification in principle and practice. J. A.tmos. Oceanic Technol. 1: 247-255

Jacques, G. (1983). Some ecophysiological aspects of Antarctic phytoplankton. Polar Biol. 2: 27-33

Joyce, T. M., Stalcup, M. E. (1985). Wintertime convection in a Gulf Stream warm-core ring. J. phys. Oceanogr. 15: 1032-1042

Lewin, J. C. (1962). Silicification. In: Lewin, R. E. (ed.) Physiology and biochemistry of algae. Academic Press, New York, p. $445-455$

Nelson, D. M. (In press). The roles of phosphorus and silicon In: Alberte, R. S., Barber, R. T (ed.) Marine photosnythesis. Oxford

Nelson, D. M., Brzezinski, M. A., Fagerness, V. L. (1982) Distribution and in situ production of biogenic silica in a Gulf Stream warm-core ring. Eos 63: 52

Nelson, D. M., Ducklow, H., Hitchcock, G. A., Brzezinski, M. A., Cowles, T J., Garside, C., Gould, R. W., Joyce, T M., Langdon, C., McCarthy, J. J., Yentsch, C. S. (1985). Distribution and composition of biogenic particulate matter in a Gulf Stream warm-core ring. Deep Sea Res, 32: $1347-1369$

Nelson, D. M., Goering, J. J. (1977). A stable isotope tracer method to measure silicic acid uptake by marine phytoplankton. Analyt. Biochem. 78: 139-147

Nelson, D. M., Goering, J. J. (1978). Assimilation of silicic acid by phytoplankton in the Baja California and northwest Africa upwelling systems. Limnol. Oceanogr. 23: 508-517

Nelson, D. M., Georing, J. J., Boisseau, D. W. (1981). Consumption and regeneration of silicic acid in three coastal upwelling systems. In: Richards, F. A. (ed.) Coastal upwelling. American Geophysical Union, Washington, p. 242-256

Nelson, D. M., Goering, J. J., Kilham, S. S., Guillard, R. R. L. (1976). Kinetics of silicic acid uptake and rates of silica dissolutoin in the marine diatom Thalassiosira pseudonana. J. Phycol. 12: 246-252 
Nelson, D. M., McCarthy, J. J., Joyce, T. M., Ducklow, H. W. (1989). Enhanced near-surface nutrient availability and new production resulting from the frictional decay of a Gulf Stream warm-core ring. Deep Sea Res. 36: 705-714

Olson, R. J., Chisholm, S. W. (1983). Effects of photocycles and periodic ammonium supply on three marine phytoplankton species. I. Cell division patterns. J. Phycol. 19: 522-528

Paasche, E. (1973a). Silicon and the ecology of marine plankton diatoms. I. Thalassiosira pseudonana (Cyclotella nana) grown in a chemostat with silicate as the limiting nutrient. Mar. Biol. 19: 117-126

Paasche, E. (1973b). Silicon and the ecology of marine plankton diatoms. II. Silicate-uptake kinetics in five diatom species. Mar. Biol. 19: 262-269

Paasche, E. (1975). Growth of the plankton diatom Thalassiosira nordenskioeldii Cleve at low silicate concentrations. J. exp. mar. Biol. Ecol. 18: 173-183

Phinney, D. A., Garside, J. C., Langton, E. W. (1984). R/V Knorr warm core rings \#3, 12-29 June, 1982. Tech. Rep. Bigelow Laboratory for Ocean Sciences \#41, p. 1-144

Phinney, D. A., Langton, E. W., Garside, J. C. (1983). R/V Knorr warm core rings \#2, 19 Apr.-6 May, 1982. Tech. Rep. Bigelow Laboratory for Ocean Sciences \#40, p. 1-108

Pratt, D. M. (1965). The winter-spring diatom flowering in Narragansett Bay. Limnol. Oceanogr 10: 173-184

Quarmby, L. M., Turpin, D. H., Harrison, P. J. (1982). Phy-

This article was submitted to the editor siological responses of two marine diatoms to pulsed additions of ammonium. J. exp. mar. Biol. Ecol. 63: 173-181

Redfield, A. C., Ketchum, B. H., Richards, F. A. (1963). The influence of organisms on the composition of seawater. In: Hill, M. N. (ed.) The sea, Vol 2. Wiley, New York, p. 26-77

Smayda, T J. (1970). The suspension and sinking of phytoplankton cells in the sea. Oceanogr. mar. Biol, A. Rev, 8: $353-414$

Sullivan, C. W. (1977). Diatom mineralization of silicic acid. II. Regulation of $\mathrm{Si}(\mathrm{OH})_{4}$ transport rates during the cell cycle of Navicula pelliculosa. J. Phycol. 13: 86-91

Thompson, T G., Robinson, R. J. (1932). Chemistry of the sea. Bull. nat. Res. Coun., Wash. 85: 95-203

Walsh, J. J., Kelley, J. C., Dugdale, R. C., Frost, B. W. (1971) Gross features of the Peruvian upwelling system with special reference to possible diel variation. Investigación pesq. 35: 25-42

Werner, D. (1977). Silicate metabolism. In: Werner, D. (ed.) The biology of diatoms. Univ. of California Press, Berkeley, p. 110-149

Wheeler, P. A., Olson, R. J., Chisholm, S. W. (1983). Effects of photocycles and periodic ammonium supply on three marine phytoplankton species. II. Ammonium uptake and assimilation. J. Phycol. 19: 528-533

Wilkinson. G. N. (1961). Statistical estimations in enzyme kinetics. Biochem. J. 890: 324-332

Manuscript first received: November 6, 1989

Revised version accepted: January 17, 1990 